Попко О. В. ${ }^{[1 ; 0 R C I D ~ I D ~: ~ 0000-0003-3356-6070], ~}$ к.е.н., доцент

${ }^{1}$ Національний університет водного господарства та природокористування, м. Рівне

\title{
ІДЕНТИФІКАЦІЯ ОСОБЛИВОСТЕЙ ФУНКЦІОНУВАННЯ ВІТЧИЗНЯНИХ ОПЕРАТОРІВ МОЛОЧНОГО РИНКУ
}

Метою наукового дослідження є підтвердження нагальної потреби підвищення конкурентоспроможності молочної продукції на вітчизняному та світових продовольчих ринках. Основну увагу приділено ідентифікації особливостей функціонування вітчизняних молокопереробних підприємств в сучасних ринкових умовах. Встановлено ключові проблеми, які перешкоджають їх подальшому розвитку. Окреслено основні напрями подолання негативних тенденцій розвитку на вітчизняному молочному ринку. Запропоновано перспективні напрями розвитку експорту вітчизняної молочної продукції.

Ключові слова: оператори ринку; ринок молока та молочної продукції; розвиток експорту.

Молокопереробна промисловість - одна з провідних галузей національної економіки, яка забезпечує населення продуктами харчування. На сьогодні можна відзначити цілу низку проблем, які перешкоджають ефективному ї̈ розвитку. Виробники молока та молочної продукції намагаються відійти від стандартів радянських часів та засвоїти нові європейські технології. Проте для успішної конкуренції 3 міжнародними виробниками потрібно подолати технологічні та фінансові проблеми, а також посилити контроль над якістю молока-сировини та готової продукції.

Дослідженню проблем ефективності розвитку молочної та молокопереробної промисловості присвячено праці провідних науковців країни, серед них: Н. Бєлінська, С. Васильчак, Т. Дудар, В. Рибінцев, Е. Смирнов, В. Смолінський, Т. Мостенська та інші. Проте потребує вирішення у короткостроковій перспективі ряд нагальних проблем, які перешкоджають ефективному розвитку молочної та молокопереробної промисловості України. Одне із завдань даного наукового дослідження спрямоване на підтвердження міркувань про нагальну потребу підвищення конкурентоспроможності вітчизняної молочної продукції й розширення товарної номенклатури експорту, а 
також диверсифікації ринків збуту й просування вітчизняних брендів на світових продовольчих ринках.

Переважна більшість з десятки кращих вітчизняних операторів ринку молока та молочної продукції $€$ одночасно як переробниками молока, так і виробниками молочної й молоковмісної продукції. Серед них молочні холдинги «Терра-Фуд», «Данон-Україна», група компаній «Молочний Альянс», ДП «Лакталіс-Україна», ТОВ «Люстдорф», ПрАТ «Вінницький молочний завод «ROSHEN»», ПрАT «Комбінат Придністровський», Компанія «Milkiland-Україна», ПрАТ «Тернопільський молокозавод» та ін. (рисунок).

\section{Переробники молока}

\section{Виробники молочної \\ та молоковмісної \\ продукції}

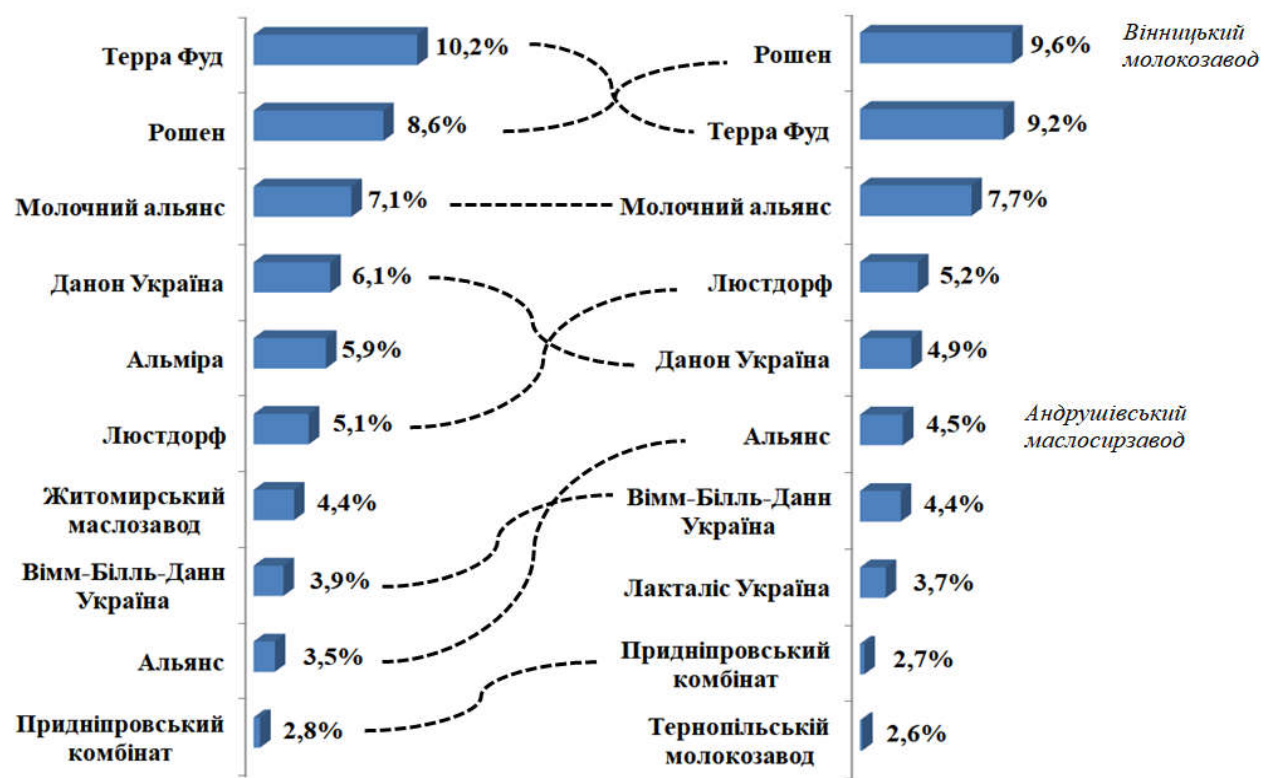

Рисунок. 10 кращих молочних компаній за часткою ринку 2017-2018 років Джерело: [14]

Присутність таких гігантів світового молочного ринку як Nestle, Lactalis, Danone в Україні спонукає операторів вітчизняного молочного ринку до удосконалення технологічних процесів та зміни концептуальних підходів у маркетинговій діяльності.

Загальна переробна потужність підприємств молочного холдингу «Терра Фуд» - понад 1,4 тис. тонн молока на день, понад 550 тис. тонн на рік. Виробничі потужності підприємств холдингу становлять понад 110 тис. тонн вершкового масла на рік, 80 тис. тонн цільномолочної продукції, 55 тис. тонн сира і 3 тис. тонн м'яких сирів. Основні бренди, представлені на українському ринку: ТМ «Ферма», 
TM «Тульчинка», ТM «Біла лінія», ТM Premialle, ТМ «Вапнярка», ТМ «Золотий резерв», ТМ «Лауреат», ТМ «Сорочинський», ТМ «Від природи». Для міжнародних ринків компанією створені бренди «100 cows», «Ukrainian Glory», «Gold Valley». Експортними поставками на базі холдингу займається ТОВ «ФУД ДЕВЕЛОПМЕНТ», виробничоторговий холдинг, заснований у 1999 році. Частка експорту по товарній групі молоко та вершки компанії в 2018 році склала $16,66 \%$. Окрім традиційних молочних продуктів, ТОВ «ФУД ДЕВЕЛОПМЕНТ» постачає молочні суміші для коктейлів і морозива у МакДональдз до Молдови, Республіки Білорусь, Азербайджану та Грузії. Також співпрацює з корпорацією «ROSHEN» та компанією «АВК» [16].

Іншим крупним оператором молочного ринку $\epsilon$ ПрАТ «Вінницький молочний завод «Roshen»» - одне 3 найбільших підприємств з виробництва молочних продуктів в Європі [3], яке спеціалізується на випуску вершкового масла, пастеризованих вершків, молочного жиру, а також різних видів сухого знежиреного молока (з різним ступенем термообробки і підвищеним вмістом білка), вершків сухих, молока згущеного. Потужність підприємства дозволяє переробляти 600 тонн молока на добу. Постачання сировини здійснюється 38 областей України. Для цього молочний завод має власне автотранспортне підприємство, з сучасними вантажними автомобілями. Потужність виробничих ліній дозволяє виробляти за добу до 48 тонн сухих молочних продуктів, до 30 тонн вершкового масла, до 18 тонн молочного жиру та до 50 тонн згущеного молока на добу. Продукція заводу експортується до більш ніж 30 країн світу, а саме: Східної Європи, Азії, Північної Америки та Африки. Частка експорту ПрАТ «Вінницький молочний завод «Roshen»» в 2018 році за товарною групою «Молоко та вершки» склала 10,25\% [16]. Вінницький молокозавод ROSHEN успішно пройшов усі дозвільні процедури і у вересні 2016 року здійснив першу поставку своєї продукції на територію $Є С$, довівши на власному прикладі, що українські підприємства можуть випускати якісні продукти і конкурувати на найвимогливіших ринках [3].

Ще одним лідером за обсягами переробки молока та виробництва молочної продукції в Україні $€$ група компаній «Молочний Альянс». Продукція «Молочного Альянсу» відома під брендами «Яготинське», «Яготинське для дітей», «Пирятин», «Славія», «Златокрай», «Молочний альянс», «Хопси». За даними компанії, в 2019 році підприємства групи переробили - 342 тис. тонн молока на рік, виготовили близько 55,5 тис. тонн молока, 42,2 тис. тонн кисломолочної продукції, 4,85 тис. тонн вершкового масла, 19,2 тис. тонн сиру, 11,65 тис. тонн дитячого харчування [4]. 
Нині, крім головної компанії, до складу холдингу входить 9 виробничих підприємств молочної галузі, серед них: ТДВ «Яготинський маслозавод», ПрАТ «Золотоніський маслоробний комбінат», ТОВ «Пирятинський сирзавод», ТДВ «Баштанський сирзавод», ПАТ «Новоархангельський сирзавод», АТ «Варвамаслосирзавод», ПрАТ «Тростянецький молочний завод», Компанія «Надія-В». Для прикладу, ТДВ «Баштанський сирзавод» за добу переробляє 350 тонн молока, ТОВ «Пирятинський сирзавод» до 500 тонн молока на добу. Завод «Яготинське для дітей», введений холдингом в експлуатацію в 2012 році, є унікальним спеціалізованим підприємством. Крім виробництва, молочний холдинг розвиває і експорт: з 2016 року здійснює експорт продукції (у тому числі сухого молока), в Європу, Китай. 32017 року підприємствами холдингу розпочато експортні поставки до США і ОАЕ. На сьогодні група компаній «Молочний Альянс» експортує свою продукцію до 35 країн, в тому числі в арабсько-мусульманські.

Молочний холдинг «Danone Україна», заснований в 2006 році, $є$ підрозділом французької продовольчої групи Danone. Потужності «Danone Україна» розташовані в Херсоні (ТОВ «Данон-Дніпро») та Кременчуці (ПрАТ «Данон-Кремез»). На базі молокопереробних підприємств «Danone Україна» щорічно переробляє 150 тис. тонн молока. «Danone Україна» спеціалізується на виробництві йогуртів, сирків і дитячого харчування під торговими марками «Активіа», «Актімель», «Живинка», «Простоквашино», «Простоквашино для малят», «Растішка», «Актуаль», «YoРro», «Даніссімо», «Paw Patrol», «Frozen», «Avengers», «Alpro». Напрямок дитячого харчування представлений в Україні брендами «Nutrilon», «Milupa» та «Малиш Істринський», напрямок клінічного харчування - продуктовими брендами: «Nutrison», «Nutridrink», «Cubitan», «Infatrini», «Nutrini», «Lophlex», «Nutri», «Anamix», «KetoCal» [8]. У 2017 році компанія інвестувала 200 млн гривень у виробництво дитячої молочної продукції. На сьогодні молокопереробне підприємство «Danone Україна» в Кременчуці випускає близько 700 тонн молочної продукції для дітей. Слід відзначити, що оператори групи «Danone Україна» дотримуються найвищих стандартів якості та безпеки продукції, надаючи перевагу натуральності й прозорості, простоті рецептури й етикетки. Так, завод «Данон-Дніпро» у Херсоні сертифіковано не лише для виробництва продукції в Україні, але й для країн ЄС. 32018 року завод почав експорт молочної продукції до Республіки Польща.

ТОВ «Люстдорф», засноване в 1997 році, входить до десятки лідерів з виробництва молочної продукції в Україні. В 2018 році 
частка ТОВ «Люстдорф» за обсягами виробленої продукції 3 незбираного молока склала 9,8\%, частка експорту за товарною групою «молоко та вершки» - відповідно 30,74\% [16], що дозволило компанії посісти перше місце в рейтингу кращих експортерів за даною групою. ТОВ «Люстдорф» функціонує на базі Іллінецького молокозаводу Вінницької області та спеціалізується на випуску сухого й питного молока, вершкового масла, молочних вершків, кисломолочної продукції під торговими марками «На здоров'я», «Корівка», «Люстдорф», «Селянське», «Тотоша», «Смачно шеф», «Бурьонка». Товарний асортимент компанії налічує більше 100 товарних позицій. Понад 50 фермерських господарств регіону постачають на промислове підприємство молоко-сировину. Нещодавно компанією запроваджено інноваційну технологію теплової обробки молока - високотемпературного імпульсу (UHTтехнологія) та паром під високим тиском. У 2016 р. компанія увійшла до офіційного списку затверджених експортерів у країни ЄС [16]. На сьогодні ТОВ «Люстдорф» експортує молочну продукцію в країни ЄС, Північної Африки, Середньої Азії, Близького Сходу.

ПрАТ «Вімм-Білль-Данн Україна» функціонує на вітчизняному ринку з 1995 року, з 2011 входить в структуру міжнародної корпорації PepsiCo, переробляє близько 175 тис. тонн молока на рік [9]. В 2018 році група компаній зайняла 8,84\% вітчизняного молочного ринку. На сьогодні до складу компанії входить два молокопереробних підприємства: ВАТ «Філія Київський міський молочний завод № 3» та ПАТ «Харківський молочний комбінат». При цьому самі заводи були введені в експлуатацію ще в 1973 році. Проєктна переробна потужність ВАТ «Філія Київський міський молочний завод № 3»- 165 тис. тонн молока на рік, в 90-х роках потужність заводу зросла до 285 тис. тонн на рік, в 2003 році після ряду модернізацій та введення в 2002 році трьох нових ліній досягла 425 тис. тонн молока на рік. В 2012 році на базі підприємства введена в експлуатацію нова автоматизована лінія з виробництва дитячого харчування (ТМ «Агуша»). У даний проєкт РерsіСо в Україні інвестувала 120 млн грн. Молочною сировиною завод забезпечують понад 50 постачальників з Київської, Житомирської, Чернігівської, Черкаської та Вінницької областей. Переробна потужність ПАТ «Харківський молочний комбінат» становить близько 150 тонн молока на добу (близько 55 тис. тонн на рік). Підприємство виробляє більше 80 видів продукції під брендами: «Ромол», «Веселий молочник», «Фругурт», «Чудо», «Слов'яночка», «Смачненько».

Французька компанія «Lactalis» присутня на вітчизняному ринку з 1996 року. В 2018 році частка ДП «Лакталіс-Україна» серед виробників продукції з незбираного молока становила 9,95\%, частка 178 
за експортом молока та молочної продукції - 24,29\%. Нині молочній групі ДП «Лакталіс-Україна» належать два молокопереробних підприємства - ПрАТ «Лакталіс-Миколаїв» (м. Миколаїв) та ТОВ «Молочний Дім» (м. Павлоград). ПрАТ «Лакталіс-Миколаїв» створено на базі Миколаївського міського молочного комбінату проєктною потужністю 450 тонн молока на добу. Виробнича потужність молокопереробного підприємства «Молочний Дім» складає 39 тис. тонн молочної продукції на рік, близько 107 тонн на добу. В Україні ДП «Лакталіс-Україна» виробляє близько 150 найменувань молочних продуктів. Найбільш відомі бренди: «President», «Galbani», «Дольче», «Фанні», «Лактонія», «Lactel». До речі, компанія однією 3 перших почала створювати пункти прийому молока у селах, обладнані спеціальними охолоджувачами та міні-лабораторіями. Зараз у ДП «Лакталіс-Україна» налічується 130 таких пунктів на території України [16]. Заводи компанії Lactalis входять у число офіційних експортерів молочної продукції до Євросоюзу. Останнім часом ДП «Лакталіс-Україна» активно розвиває експорт, експортуючи свою продукцію в Молдову, Грузію, ОАЕ, Мальдіви, Саудівську Аравію [10].

ПрАТ «Комбінат «Придніпровський» був заснований в 1990 році на базі Дніпропетровського міського молокозаводу № 2, введеного в експлуатацію в 1976 році. До компанії входять чотири молокопереробні підприємства: ДП «Васильківський сирзавод», ДП «Царичанський маслозавод», Перещепинський молочний цех, Новомосковський цех 3 виробництва фруктових наповнювачів. Щодня підприємства компанії переробляють понад 250 тонн молока, яке надходить з п'яти ферм, розташованих у Дніпропетровській області. Свою продукцію комбінат «Придніпровський» випускає під торговими марками «Злагода» i «Любимчик». Для виробництва кисломолочних продуктів за старовинною рецептурою компанія провела реконструкцію і встановила термостатні камери. Комбінат входить до четвірки найбільших виробників в Україні дитячого молока, рідкої молочної суміші і кисломолочних продуктів під торговою маркою «Злагода». Крім виробництва кисломолочних продуктів і дитячого харчування, компанія розвиває власну мережу магазинів виїзної торгівлі, а також займається виробництвом телета кінофільмів [13]. Частка експорту ПрАТ «Комбінат «Придніпровський» по товарній групі «Молоко та вершки» в 2018 році становила 1,93\% [16].

ПрАТ «Тернопільський молокозавод» засновано в 2000 році. На вітчизняному ринку компанію представлено широким асортиментом, який налічує молоко, масло, кефір, сметану, йогурти і сири під 
торговою маркою «Молокія» [12]. Потужності ПрАТ «Тернопільський молокозавод» дозволяють переробляти 300 тонн молока на день. У 2018 році компанія посіла $5,2 \%$ на вітчизняному молочному ринку. Компанія закуповує сировину безпосередньо 3 фермерських господарств. 32014 року ПрАТ «Тернопільський молокозавод» першим в Україні почав застосовувати німецьку технологію Fresh milk Technology, яка дозволяє пастеризувати молоко при низькій температурі (близько $75^{\circ} \mathrm{C}$ ) протягом 30 секунд. Така теплова обробка дозволяє зберегти вітаміни і корисну мікрофлору. У компанії 13 торгових представництв в Україні. Тернопільський молокозавод співпрацює з польською компанією Mlekovita, яка під торговою маркою «Молокія» запустила лінійку твердих сирів «Голландський», «Маздамер» і «Тильжицький». Близько 20\% вершкового масла і весь казеїн підприємство експортує. Географія експорту: Республіка Польща, Німеччина, Голландія, Латвія, США, Грузія, Марокко, у планах - країни ЄС та Близького Сходу.

Компанії «Milkiland Україна» належить шість сироробних заводів і чотири заводи з виробництва продукції з незбираного молока, серед них: Філія «Менський сир» (Чернігівська область), ПАТ «Чернігівський молокозавод» (м. Чернігів), Філія «Охтирський сиркомбінат» ПП«Рось» (Сумська область), Філія «Сумський молочний завод» (м. Суми), Філія «Конотопський молочний завод» (Сумська область), Філія «Роменський молочний комбінат» (Сумська область), ТОВ «Миргородський сироробний комбінат» (Полтавська область), ДП «Агролайт» (Дніпропетровська область), Філія «Львівський молочний комбінат» (м. Львів), Філія «Славутський маслоробний комбінат» (Хмельницька область) [11]. Філія «Менський сир» $€$ лідером з випуску сирів і молочної сироватки серед заводів «Milkiland Україна» та виробляє тверді сири («Король Артур» зі смаком пряженого молока, «Російський великий», «Сметанковий», «Вершковий», «Преміум», «Мисливський» зі спеціями, «Дуплет», «Мармуровий», «Едем», «Пармезан», «Королівський», «Радомер», «Норвезький», «Мааздам», «Фараон», «Фамільний», «Норвезький» копчений), вершкове масло («Селянське», «Екстра»), суху сироватку та сири м'які («Камамбер», «Камамбер» з кешью, «Камамбер» 3 грибами, «Камамбер» із зеленим перцем, «Брі», «Брі з кешью», «Брі 3 грибами», «Брі з паприкою»). Для того, щоб компенсувати втрату російського ринку, компанія «Milkiland Україна» налагодила експорт більш ніж до 30 країн. На сьогодні компанія намагається закріпитися на польському ринку сиру. Зокрема, Мазовецький сироробний завод «Островія» виготовляє та постачає до країн ЄС білковий концентрат. З 2016 року «Milkiland Україна» почала поставляти сухе молоко до 
Китаю.

Узагальнюючу інформацію щодо часток, які займають ключові гравці на вітчизняному молочному ринку, торгові марки, під якими представлено їхню молочну продукцію на ринку, наведено нами на рис. 2. Загалом провідні вітчизняні виробники молочної продукції використовують високоякісну молоко-сировину, у тому числі екстракласу, вищого, першого ґатунків. При цьому за даними офіційної статистики 2018 року левова частка молока-сировини надходить у переробку від сільськогосподарських підприємства. Для прикладу, на окремих підприємствах Групи компаній «Молочний Альянс», зокрема ТДВ «Яготинський маслозавод», у переробку надходить виключно молоко від сільськогосподарських підприємств, на ТДВ «Баштанівський сирзавод» - 60\% сировини надходить від сільськогосподарських підприємств, 40\% - від населення; на ТОВ «Пирятинський сирзавод» і ПрАТ «Золотоніський маслоробний комбінат» - 50\% надходить від сільськогосподарських підприємств, 40\% - від населення [7]. На ДП «Лакталіс-Україна» 97\% молокасировини надходить з великих сільськогосподарських ферм, 3\% - від господарств населення. Окремі оператори відзначили, що мають замкнені виробничі цикли та виробляють молочну продукцію 3 молока власних ферм (підприємства «Білоцерківської агропромислової групи», Компанія «Органік Мілк»).

Водночас оператори ринку мають певні перестороги щодо дефіциту молочної сировини на внутрішньому ринку вже в поточному 2020 році через суттєве скорочення обсягів молокасировини внаслідок скасування 1 січня 2020 року другого ґатунку молока, що передбачено новим ДСТУ «3662:2018 «Молоко-сировина коров'яче. Технічні умови» [6]. Таке рішення зумовлено ще й тим, що європейські стандарти передбачають відмову від використання молока другого ґатунку, хоча сучасні технології дозволяють його переробляти. Згідно з прогнозами експертів молочного ринку на 2020 рік, молокопереробні підприємства недоотримають близько 1 млн тонн молока другого ґатунку, основним виробником якого $\epsilon$ господарства населення. Дефіцит сировини зумовлено ще й всеукраїнською тенденцією до скорочення кількості голів худоби. За даними Держстату [2], на 1 січня 2020 року поголів'я великої рогатої худоби (BPX) в Україні становило близько 3,14 млн голів, що на 5,7\% менше, ніж на 1 січня 2019 року. 

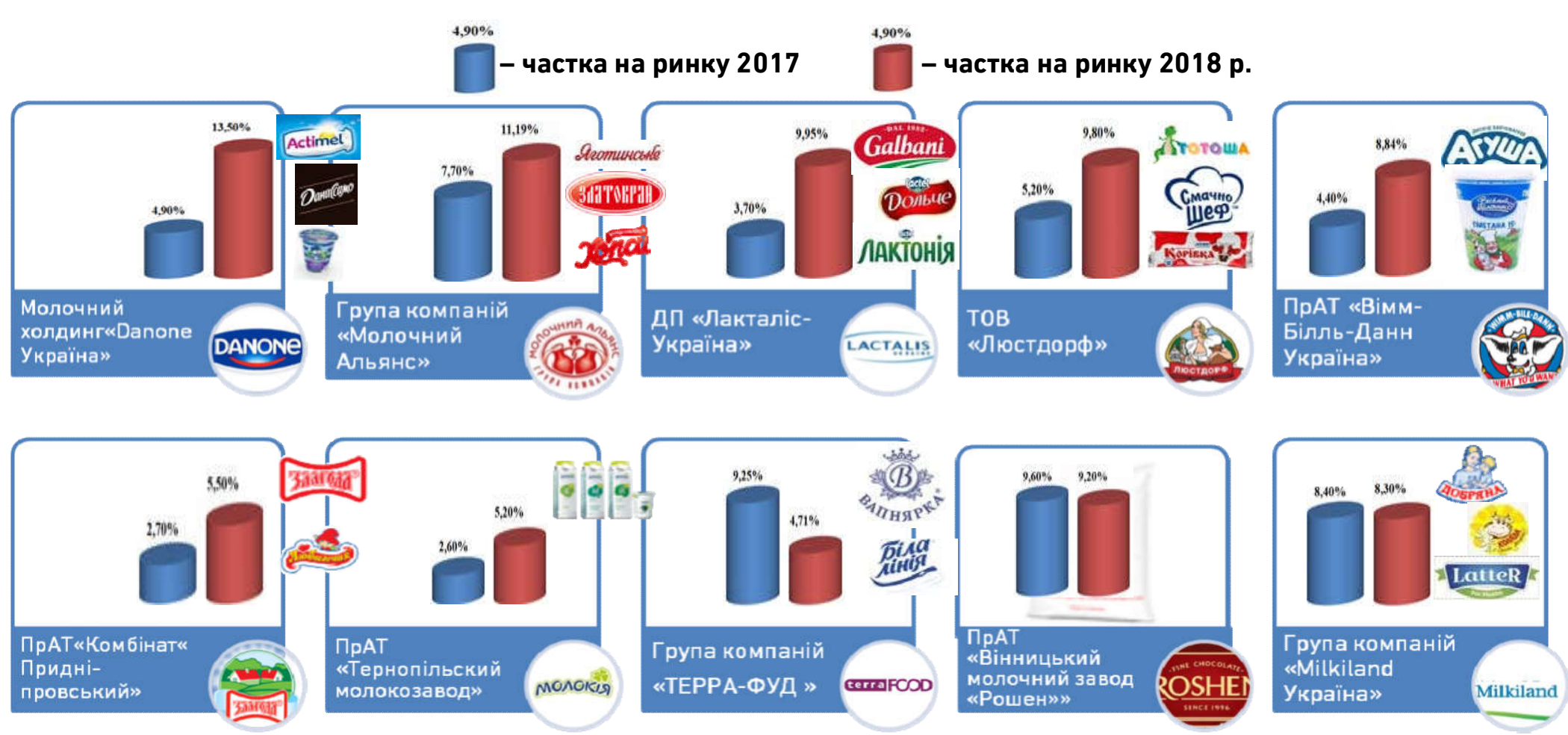

Рис. 2. Торгові марки провідних операторів вітчизняного ринку молока та молочної продукції Джерело: розроблено автором 
У тому числі сільськогосподарські підприємства утримували 1,05 млн голів BPX, що на 7,5\% менше, ніж на 1 січня 2019 року, господарства населення - 2,09 млн голів, що на 4,7\% менше ніж на 1 січня 2019 року. А все через те, що тримати корову стає невигідно й дорого. Маленькі ферми, які придбали корів, можуть вийти на точку беззбитковості приблизно через 8-10 років. А ще після останніх змін у законодавстві щодо запровадження вільного ринку землі підприємці бояться опинитися в боргах [17].

Викликає й пересторогу нарощення імпорту молочної продукції, особливо в частині твердих сирів, обсяги якого в 2019 році суттєво перевищили обсяги експорту в 2018 році в 2,6 рази, що підтверджується даними Державної фіскальної служби України [5]. Така ситуація, на думку керівника департаменту тваринництва Групи компаній Ukrlandfarming В. Педана «...є критичною в цілому, оскільки напряму впливає на продовольчу безпеку держави» [18]. На його думку, таке становище спричинено непродуманою системою дотацій для товаровиробників, низьким експортним потенціалом переробників молока та низькою покупною спроможністю населення України. Проте у разі, якщо до 2022 року відбудеться стандартизація і сертифікація продукції, без яких фермер не зможе продавати на ринку молоко-сировину, то питання щодо якості зніметься, а крупні оператори ринку зможуть додатково закуповувати молоко саме в населення, до того ж у більших обсягах.

Разом 3 тим, українці споживають молока та молочних продуктів значно менше за фізіологічну норму. При цьому негативна тенденція до скорочення споживання молока та молочної продукції населенням України спостерігається і в динаміці. Підтвердженням цього $€$ офіційні дані Державної служби статистики України [1], зокрема скорочення споживання молока та молочних продуктів населенням України з 225,6 кг/особу в 2005 році до 200,0 кг/особу в 2017 році.

За даними OECD-FAO Agricultural Outlook 2019-2028 [19], середній показник споживання молочних продуктів в Україні в 20152017 роках має ще менше значення - 164,4 кг/особу. Згідно 3 рекомендаціями світових організацій в галузі харчування [20], добова норма споживання молочних продуктів має становити 2-3 порції молочних продуктів в день, при цьому одна порція прирівнюється до склянки рідкого молочного продукту або 40 г твердого сиру.

Причинами скорочення споживання молока та молочних продуктів є зниження купівельної спроможності населення України 
за одночасного зростання закупівельних цін на молоко-сировину, які в жовтні 2019 року сягнули максимуму в гривневому вимірі за період незалежності України, у тому числі через дефіцит вихідної сировини на фоні зростання матеріальних витрат промислових підприємств [17].

Переважна більшість операторів відзначають, що сьогодні ключовим завданням для вітчизняних молокопереробних підприємств $\epsilon$ забезпечення населення України якісними та безпечними для здоров'я молочними, продуктами. До ключових ринкових трендів, які сьогодні враховуються операторами молочного ринку, належать:

1) зростання попиту на безпечні для здоров'я натуральні харчові, у тому числі молочні продукти;

2) відповідність високим гігієнічним стандартам та стандартам безпечності харчових продуктів;

3) розвиток культури споживання, яка базується на екологічних міркуваннях.

3 огляду на вищевикладене, до перспектив розвитку молочного напрямку вітчизняними операторами ринку можна віднести:

1) орієнтація на споживача шляхом врахування смаків та вподобань цільових категорій споживачів, пропонуючи молочну продукцію з найвищими органолептичними показниками, широким асортиментом, ціновою доступністю, широкою географією продажів, таку, що відповідає концепції здорового харчування;

2) забезпечення високих стандартів якості, підтверджених сертифікатами відповідності міжнародним стандартам якості та безпеки на всіх етапах виробництва від початкового джерела сировини і до полиць в торговельних мережах;

3) освоєння нових сегментів молочного ринку, розвиток інноваційних категорій молочних продуктів шляхом використання досвіду професіоналів галузі, передових технологій, новітнього обладнання.

Висновки. Молокопереробна галузь України характеризується високим рівнем конкуренції, має значний потенціал для нарощування обсягів виробництва та отримання стабільних доходів. Дослідження показало, що існують певні проблеми, які стримують розвиток галузі, серед яких скорочення поголів'я корів, зниження обсягів виробництва молока-сировини, низька покупна спроможність населення на внутрішньому ринку, зростання імпорту за окремими групами молочної продукції. Натомість у якості перспективних напрямів розвитку галузі можна розглядати фокусування на нових інноваційних видах молочної продукції 3 184 
визначеним функціональним призначенням для вузьких цільових сегментів споживачів та диверсифікацію ринків збуту.

1. Баланси та споживання основних продуктів харчування населенням України: статистичний збірник. Київ : Державна служба статистики України, 2018. 59 с. 2. В Україні скорочується поголів'я більшості видів сільгосптварин: вебсайт. URL: https://www.ukrinform.ua/rubric-economy/2857755-v-ukraini-skorocuetsa-pogolivabilsosti-vidiv-silgosptvarin.html (дата звернення: 04.04.2020). 3. Вінницький молочний завод «Roshen»: вебсайт. URL: https://www.roshen.com/ua/ua/proroshen/fabryky-i-zavody/prat-vinnyc-kyj-molochnyj-zavod-roshen (дата звернення: 01.04.2020). 4. Група «Молочний альянс» : вебсайт. URL: https://milkalliance.com.ua (дата звернення: 01.04.2020). 5. Державна фіскальна служба України: вебсайт. URL: http://sfs.gov.ua/ms/f11http://avm-ua.org/uk/post/97-ukrinskogo-kazeinu eksportuut?milkua=0 (дата звернення: 05.06.2019). 6. ДСТУ 3662: 2018. Молокосировина коров'яче. Технічні умови. [Чинний від 2019-01-01]. Київ, 2018. 12 с. (Інформація та документація). 7. За год вложим не менее 200 млн грн инвестиций глава набсовета ГК «Молочный альянс»: вебсайт. URL: https://interfax.com.ua/ news/interview/601083.html (дата звернення: 03.04.2020). 8. Компанія Danone: вебсайт. URL: http://danone.ua (дата звернення: 01.04.2020). 9. Вімм-Білль-ДаннУкраїна: вебсайт. URL: http://www.wimm-bill-dann.com.ua/ (дата звернення: 02.04.2020). 10. Лакталіс в Україні : вебсайт. URL: https://lactalis.com.ua (дата звернення: 02.04.2020). 11. Милкиленд : вебсайт. URL: http://milkiland.ua/ru/ (дата звернення: 02.04.2020). 12. Молокія: вебсайт. URL: https://molokija.com (дата звернення: 02.04.2020). 13. ПрАТ «Комбінат «Придніпровський»: вебсайт. URL: http: //zlagoda.dp.ua/about/ (дата звернення: 02.04.2020). 14. Статистичний довідник Агробізнес України 2018. Агробізнес України: вебсайт. URL: https://agribusinessinukraine.com/the-infographics-report-ukrainian-agribusiness2018 (дата звернення: 14.11.2019). 15. Терра-Фуд: вебсайт. URL: https://terrafood.ua (дата звернення: 01.04.2020). 16. ТОП-10 експортерів та імпортерів молока і вершків: вебсайт. URL: https://agravery.com/uk/posts/show/top-10-eksporteriv-ta-importeriv-moloka-iverskiv (дата звернення: 01.04.2020). 17. Чуже молоко : вебсайт. URL: https://zaxid.net/projects/milk (дата звернення: 03.04.2020). 18. Экспорт молочной продукции. Сегодня: вебсайт. URL: https://www.segodnya.ua/economics/enews/skolko-molochnyh-produktov-prodalaukraina-nazvany-glavnye-strany-pokupateli-1254460.html (дата звернення: 16.04.2019). 19. OECD-FAO Agricultural Outlook 2018-2027. URL: http://www.agrioutlook.org (access date: 24.01 2020). 20. ChooseMyPlate. URL: https://goo.gl/RoU4FY (access date: 03.04.2020).

\section{REFERENCES:}

1. Balansy ta spozhyvannia osnovnykh produktiv kharchuvannia naselenniam Ukrainy: statystychnyi zbirnyk. Kyiv : Derzhavna sluzhba statystyky Ukrainy, 2018. 59 s. 2. V Ukraini skorochuietsia poholivia bilshosti vydiv silhosptvaryn : vebsait. URL: https://www.ukrinform.ua/rubric-economy/2857755-v-ukraini-skorocuetsa-pogolivabilsosti-vidiv-silgosptvarin.html (data zvernennia: 04.04.2020). 3. Vinnytskyi molochnyi zavod «Roshen» : vebsait. URL: https://www.roshen.com/ua/ua/pro-roshen/fabryky-izavody/prat-vinnyc-kyj-molochnyj-zavod-roshen (data zvernennia: 01.04.2020). 4. Hrupa «Molochnyi alians» : vebsait. URL: https://milkalliance.com.ua (data 
zvernennia: 01.04.2020). 5. Derzhavna fiskalna sluzhba Ukrainy : vebsait. URL: http://sfs.gov.ua/ms/f11http: //avm-ua.org/uk/post/97-ukrinskogo-kazeinu eksportuut?milkua=0 (data zvernennia: 05.06.2019). 6. DSTU 3662: 2018. Molokosyrovyna koroviache. Tekhnichni umovy. [Chynnyi vid 2019-01-01]. Kyiv, 2018. 12 s. (Informatsiia ta dokumentatsiia). 7. Za god vlojim ne menee $200 \mathrm{mln}$ grn investitsiy glava nabsoveta GK «Molochnyiy alyans»: vebsait. URL: https://interfax.com.ua/ news/interview/601083.html (data zvernennia: 03.04.2020). 8. Kompaniia Danone : vebsait. URL: http://danone.ua (data zvernennia: 01.04.2020). 9. Vimm-Bill-DannUkraina : vebsait. URL: http://www.wimm-bill-dann.com.ua/ (data zvernennia: 02.04.2020). 10. Laktalis v Ukraini : vebsait. URL: https://lactalis.com.ua (data zvernennia: 02.04.2020). 11. Mylkylend : vebsait. URL: http://milkiland.ua/ru/ (data zvernennia: 02.04.2020). 12. Molokiia : vebsait. URL: https://molokija.com (data zvernennia: 02.04.2020). 13. PrAT «Kombinat «Prydniprovskyi» : vebsait. URL: http: //zlagoda.dp.ua/about/ (data zvernennia: 02.04.2020). 14. Statystychnyi dovidnyk Ahrobiznes Ukrainy 2018. Ahrobiznes Ukrainy : vebsait. URL: https://agribusinessinukraine.com/the-infographics-report-ukrainian-agribusiness2018 (data zvernennia: 14.11.2019). 15. Terra-Fud : vebsait. URL: https://terrafood.ua (data zvernennia: 01.04.2020). 16. TOP-10 eksporteriv ta importeriv moloka i vershkiv : vebsait. URL: https://agravery.com/uk/posts/show/top-10-eksporteriv-ta-importerivmoloka-i-verskiv (data zvernennia: 01.04.2020). 17. Chuzhe moloko : vebsait. URL: https://zaxid.net/projects/milk (data zvernennia: 03.04.2020). 18. Eksport molochnoy produktsii.

Segodnya vebsait.

URL: https://www.segodnya.ua/economics/enews/skolko-molochnyh-produktov-prodalaukraina-nazvany-glavnye-strany-pokupateli-1254460.html (data zvernennia: 16.04.2019). 19. OECD-FAO Agricultural Outlook 2018-2027. URL: http ://www.agrioutlook.org (access date: 24.01.2020). 20. ChooseMyPlate. URL: https://goo.gl/RoU4FY (access date: 03.04.2020).

Popko 0. V. [1; ORCID ID: 0000-0003-3356-6070], Candidate of Economics (Ph.D.), Associate Professor

${ }^{1}$ National University of Water and Environmental Engineering, Rivne

\section{IDENTIFICATION OF FEATURES OF FUNCTIONING OF DOMESTIC DAIRY MARKET OPERATORS}

The dairy industry of Ukraine is characterized by a high level of competition; it has significant potential for increasing production and obtaining stable incomes. The research showed that there are certain problems that hinder the development of the industry including the reduction of cows, reduced production of raw milk, and low purchasing power of the population in the domestic market, increasing imports by certain groups of dairy products. Solving the problems of the dairy industry of Ukraine and developing strategies for its further development is impossible without in-depth analysis and identification of the peculiarities of the functioning of domestic dairy market operators. The vast majority of the TOP-10 domestic operators of the milk and dairy products market are both milk processors and producers of dairy and milk-containing products. 
Among them are dairy holdings «Terra-Food», «Danone-Ukraine», group of companies «Dairy Alliance», SE «Lactalis-Ukraine», LLC «Lustdorf», PJSC «Vinnytsia Dairy Plant», «ROSHEN», PJSC «Transnistrian Plant», «MilkilandUkraine Company», PJSC «Ternopil Dairy Plant». At the same time, the presence of such giants of the world dairy market as Nestle, Lactalis, Danone in Ukraine encourages operators of the domestic dairy market to improve technological processes and change conceptual approaches in marketing.

There are several prospects for the development of the dairy direction by domestic market operators. They include 1) consumer orientation by taking into account the tastes and preferences of certain target categories of consumers; 2) ensuring high standards of quality and safety from the initial source of raw materials to the final consumer; 3 ) development of innovative categories of dairy products through the use of experience of industry professionals, advanced technologies, the latest equipment.

Focusing on new innovative types of dairy products with a specific functional purpose, on narrow target segments of consumers, and on new geographical segments of dairy sales can be considered as promising areas of development of the dairy industry of Ukraine.

Keywords: market operators; milk and dairy products market; export development.

Попко Е. В. ${ }^{[1 ; ~ O R C I D ~ I D: ~ 0000-0003-3356-6070], ~}$ к.э.н., доцент

${ }^{1}$ Национальный университет водного хозяйства и природопользования, г. Ровно

\section{ИДЕНТИФИКАЦИЯ ОСОБЕННОСТЕЙ ФУНКЦИОНИРОВАНИЯ ОТЕЧЕСТВЕННЫХ ОПЕРАТОРОВ МОЛОЧНОГО РЫНКА}

Целью научного исследования является подтверждение необходимости повышения конкурентоспособности молочной продукции на отечественном и мировых продовольственных рынках. Основное внимание уделено идентификации особенностей функционирования отечественных молокоперерабатывающих предприятий в современных рыночных условиях. Установлено ключевые проблемы, которые препятствуют их дальнейшему развитию. Определены основные направления преодоления негативных тенденций развития отечественного молочного рынка. Предложены перспективные направления развития экспорта отечественной молочной продукции.

Ключевые слова: операторы рынка; рынок молока и молочной продукции; развитие экспорта. 